\title{
Glucose transporter 1 expression accompanies hypoxia sensing in the cyclic canine corpus luteum
}

\author{
Paula de Carvalho Papa, Liza Margareth Medeiros de Carvalho Sousa, Renata dos Santos Silva, \\ Luciana Alves de Fátima, Vanessa Uemura da Fonseca, Vanessa Coutinho do Amaral, \\ Bernd Hoffmann ${ }^{1}$, Ana Bárbara Alves-Wagner ${ }^{2}$, Ubiratan Fabres Machado ${ }^{2}$ and \\ Mariusz Pawel Kowalewski ${ }^{3}$
}

\begin{abstract}
Sector of Anatomy, Department of Surgery, Faculty of Veterinary Medicine and Animal Sciences, University of São Paulo, Av. Prof. Dr Orlando Marques Paiva, 87, CEP 05508-270 São Paulo, Brazil, ${ }^{1}$ Clinic for Obstetrics, Gynecology and Andrology of Large and Small Animals, Justus-Liebig Universitaet, Giessen, Germany, ${ }^{2}$ Department of Physiology and Biophysics, Institute of Biomedical Sciences, University of São Paulo, São Paulo, Brazil and ${ }^{3}$ Institute of Veterinary Anatomy, University of Zurich, Zurich, Switzerland
\end{abstract}

Correspondence should be addressed to P C Papa; Email: ppapa@usp.br

\begin{abstract}
The canine corpus luteum $(C L)$ functions as a source of progesterone $\left(P_{4}\right)$ and $17 \beta$-oestradiol $\left(E_{2}\right)$; however, the transport of energy substrates to maintain its high hormonal output has not yet been characterised. This study involved the localisation and temporal distribution of the facilitative glucose transporter 1 and the quantification of the corresponding protein (GLUT1) and gene (SLC2A1) expression. Some GLUT1/SLC2A1 regulatory proteins, such as hypoxia-inducible factor $1 \propto(\mathrm{HIF} 1 \mathrm{~A})$ and fibroblast growth factor 2 (FGF2); mRNAs, such as HIF1A, FGF2 and vascular endothelial growth factor A (VEGFA); and VEGFA receptors 1 and 2 (FLT1 and KDR) were also analysed from days 10 to 70 after ovulation. Additionally, plasma $P_{4}$ and $E_{2}$ levels were assessed via chemiluminescence. Moreover, the canine KDR sequence has been cloned, thereby enabling subsequent semi-quantitative PCR analysis. Our results demonstrate time-dependent variations in the expression profile of $S L C 2 A 1$ during dioestrus, which were accompanied by highly correlated changes $(0.84<r<0.98 ; P<0.03)$ in the gene expression of HIF1A, VEGF and FLT1 as well as in $\mathrm{P}_{4}$ plasma concentrations. FGF2 mRNA correlated with $E_{2}$ plasma concentrations $(r=0.61 ; P=0.01)$. Our data reveal that the glucose transporter is regulated throughout the $C L$ lifespan and suggest that $C L$ depends on the sensing of hypoxia and the status of luteal vascularisation. Moreover, time-dependent expression of GLUT1/SLC2A1 may lie underneath increased metabolic and energetic requirements for sustaining $\mathbf{P}_{\mathbf{4}}$ production.

Reproduction (2014) 147 81-89
\end{abstract}

\section{Introduction}

The reproductive cycle of non-pregnant dogs is distinct from other species and is characterised by a long corpus luteum (CL) phase (dioestrus), which can last over 60-80 days with regression occurring despite the presence of a uterine luteolysin (Hoffmann et al. 1992). During this time, the $\mathrm{CL}$ undergoes morpho-endocrinological changes in response to gonadotrophic stimuli and local regulatory factors (Hoffmann et al. 2004, Kowalewski et al. 2008a, 2009, Papa \& Hoffmann 2011). Morphological changes following ovulation until late in dioestrus (Sonnack 2009) as well as changes in steroid hormone, prostaglandin and cytokine levels have been described to act as local regulatory factors (Engel et al. 2005, Kowalewski et al. 2008a, 2008b, Papa \&
Hoffmann 2011). The lifespan of the CL depends on energetic supply (Downing et al. 1995), which may be regulated by steroid hormones (Frolova et al. 2009): in endometrial cells, progesterone $\left(\mathrm{P}_{4}\right)$ directly regulates the expression of glucose transporter type 1 (SLC2A1 gene/GLUT1 protein) through its receptor (Kim \& Moley 2009), activating the signalling pathway Akt/PKA/ PRKAA and increasing the expression and translocation of GLUT1 (Kim \& Moley 2009), the most ubiquitously distributed facilitative glucose transporter responsible for taking up glucose at basal conditions (Palfreyman et al. 1992). Besides steroid hormones, the hypoxia-inducible factor $1 \alpha$ (HIF1A) has been implicated as a potent inducer of GLUT1 and of its gene SLC2A1 (Takagi et al. 
1998, Sone et al. 2000, Zhao \& Keating 2007, Kihira et al. 2011, Mattmiller et al. 2011). HIF1A represents the inducible portion of the HIF1 protein, which is a specialised sensor for variations in oxygen tension in different tissues (Wang \& Semenza 1993). The CL is a dynamic endocrine gland formed under low oxygen tension after follicular rupture (Neeman et al. 1997, van den Driesche et al. 2008), and its HIF1A content oscillates over dioestrus, mirroring that of $\mathrm{CL}-\mathrm{pO}_{2}$ and participating in $\mathrm{CL}$ development and regression, which has been shown for both the primate (Duncan et al. 2008) and bovine CL (Nishimura et al. 2008, 2010).

The formation of the $\mathrm{CL}$ and maintenance of its function also strongly depend on the vascular endothelial growth factor A (VEGFA) system (Ferrara et al. 1998, Nishimoto et al. 2006). The spatio-temporal expression of VEGFA and its receptors, FLT1 and KDR, in the canine $\mathrm{CL}$, has been assessed during dioestrus (Mariani et al. 2006), and the results suggest that this angiogenic factor plays a local paracrine and autocrine role. As observed in humans, in mice, as well as in cattle, the luteal VEGFA expression also highly correlates with HIF1A expression levels, which results in the transcription of VEGF (van den Driesche et al. 2008, Nishimura \& Okuda 2010, Zhang et al. 2011). Another important angiogenic factor, fibroblast growth factor 2 (FGF2), has also been shown to regulate GLUT1 expression through HIF1A. Using RNA silencing specific for HIF1A, decreased FGF2-induced SCL2A1 expression was observed in 3T3-L1 adipocytes (Kihira et al. 2011), while the expression of FGF2 in canine ovaries, specifically during follicular development, has been reported (Songsasen et al. 2009); to the best of our knowledge, no time-related changes during dioestrus have been reported for canine CL. Similarly, no data have been published on the effect of $\mathrm{pO}_{2}$, the expression of HIF1A or its possible association with the expression of glucose transporters and angiogenic factors in the $\mathrm{CL}$ of non-pregnant bitches.

Therefore, we hypothesised that the expression of GLUT1 in the canine CL is associated with time-related vascular and oxygen changes during dioestrus. To test this hypothesis, the spatio-temporal expression of GLUT1, the regulatory factors HIF1A, FGF2 and VEGFA, as well as the VEGFA receptors FLT1 and KDR (VEGFA system) were investigated and the expression patterns correlated with the steroid hormone profile during dioestrus.

\section{Materials and methods \\ Dogs and experimental design}

Twenty-eight healthy mongrel female dogs belonging to 'Santuário' dog shelter (Sao Paulo, Brazil) were included in the study. After the onset of pro-oestrous bleeding, blood samples were collected every other day to determine the
$\mathrm{P}_{4}$ concentrations. The day of ovulation was considered the day when $\mathrm{P}_{4}$ plasma concentrations reached $5 \mathrm{ng} / \mathrm{ml}$ (Concannon et al. 1989). Seven groups ( $n=4$ animals per group) were established. The CLs were harvested via ovariohysterectomy on days 10, 20, 30, 40, 50, 60 and 70 after ovulation (p.o.), covering the entire period of dioestrus. The experimental protocol, including anaesthesia (acepromazine, $0.2 \mathrm{mg} / \mathrm{kg}$ i.m.; xylazine, $3 \mathrm{mg} / \mathrm{kg}$ and ketamine, $5-8 \mathrm{mg} / \mathrm{kg}$ i.v.) and surgery, was approved by the Committee of Ethics in the Use of Animals of the Faculty of Veterinary Medicine and Animal Science, University of Sao Paulo, Sao Paulo, Brazil (protocol number 1432/2008). After collection, the $\mathrm{CL}$ were dissected from the surrounding ovarian tissue and immediately frozen in liquid nitrogen for total RNA and protein extraction or fixed in $4 \%$ buffered formalin for $24 \mathrm{~h}$ for immunohistochemistry. The following parameters were assessed: VEGFA, FLT1, KDR, SCL2A1, HIF1A and FGF2 mRNA expression and GLUT1, HIF1A and FGF2 protein expression. Blood samples $(5 \mathrm{ml})$ were collected on the day of surgery prior to anaesthesia for measurement of $17 \beta$-oestradiol $\left(E_{2}\right)$ and $P_{4}$ levels.

\section{Molecular cloning of canine KDR}

As the sequence of canine KDR has not yet been reported, homology cloning was performed as described previously (Kowalewski \& Hoffmann 2008), using mRNA derived from four different bitches to determine the cDNA coding of canine KDR. Primers for qualitative PCR were derived from the alignment of the predicted canine KDR sequence (GI: 73975290; www.ncbi.nlm.nih.gov/genome/guide/dog/ index.html) with predicted bovine and available mouse and pig sequences (GenBank accession numbers: bovine Gl: 61884824; mouse Gl: 27777647 and pig Gl: 7160277). A 4068-bp cDNA fragment PCR product of the predicted open reading frame (ORF) of canine KDR was amplified. Total RNA was isolated from canine $\mathrm{CL}$ with TRIzol Reagent according to the manufacturer's protocol (Gibco-BRL, Life Technologies). DNase treatment and RT-PCR were performed using the GeneAmp Gold RNA PCR Kit (Perkin-Elmer Applied Biosystems GmbH, Weiterstadt, Germany) as described previously (Kowalewski et al. 2006). The annealing temperature was $58.5^{\circ} \mathrm{C}$. PCR products were separated on a $2 \%$ ethidium bromide-stained agarose gel, purified using the Qiaex II gel extraction system (Qiagen $\mathrm{GmbH})$, ligated into the pGEM-T vector (Promega), amplified in XL1 BLUE competent cells (Stratagene, La Jolla, CA, USA) and sequenced on both strands (SRD, Oberursel, Germany) with T7 and Sp6 sequencing primers. For every experiment, autoclaved water was used instead of RNA as negative control. RNA integrity and the assay procedure were tested via amplification of the reference gene glyceraldehyde-3-phosphate dehydrogenase. Finally, the cloned cDNA sequence was submitted to GenBank with access number DQ269018.1 Canis familiaris KDR, complete cds. The prediction of the amino acid sequence and sequence comparison was performed using ChromasPro version 1.2 oligo Software (Technelysium Pty. Ltd., Brisbane, Queensland, Australia). 


\section{RNA extraction and RT}

The CLs were homogenised with TRIzol Reagent using a Bio-gen Pro 200 homogeniser (Pro Scientific, Inc., Oxford, CT, USA). This step was followed by chloroform/isopropanol/ ethanol extraction, as recommended by the manufacturer (Invitrogen). RNA concentration and quality were assessed via spectrometry using a BioPhotometer (Eppendorf, Hamburg, Germany), and integrity verification was performed with a $2 \%$ agarose gel. Following the DNase treatment, $1 \mu \mathrm{g}$ total RNA per sample was reverse transcribed using a Superscript III Kit (Invitrogen).

\section{Real-time PCR}

Real-time PCR analyses were performed using an ABI 7500 Sequence Detection System (PE Applied Biosystems) as described previously (Campos et al. 2010) with some modifications to match dog-specific conditions, such as the low concentrations of available cDNA. SLC2A1, HIF1A, VEGFA, FLT1, KDR and FGF2 primers and probes were designed using the Assays-by-Design service from Applied Biosystems (Table 1). Cyclophilin A was used as the reference gene, as determined by NormFinder Software (Arhus, Ârhus, Denmark; Andersen et al. 2004). In 96-well plates, 125 ng cDNA diluted in $2.5 \mu \mathrm{l}$ nuclease-free water were added to a mixture containing $6.25 \mu \mathrm{l}$ TaqMan Universal PCR Master Mix buffer ( $2 \times$, Applied Biosystems). Additionally, $0.5 \mu \mathrm{l}$ of both forward and reverse primers $(900 \mathrm{mM}), 250 \mathrm{mM}$ probe (Applied Biosystems) and $3.25 \mu \mathrm{l}$ water were added to a final volume of $12.5 \mu \mathrm{l}$. All plates were sealed with MicroAmp Optical Adhesive Covers (Applied Biosystems) following the complete mixture of all reagents and subsequent centrifugation. The following cycling parameters were applied: $2 \mathrm{~min}$ at $50{ }^{\circ} \mathrm{C}$, $10 \mathrm{~min}$ at $95^{\circ} \mathrm{C}$ and 40 cycles of $15 \mathrm{~s}$ at $95^{\circ} \mathrm{C}$ (denaturation) and $1 \mathrm{~min}$ at $60^{\circ} \mathrm{C}$ (annealing and extension). PCR assays for target genes were conducted at least in quadruplicate for each sample, and the expression level was determined using relative quantification via linear regression of the fluorescence data. The ratios were calculated using the equation 'relative expression = NO (target gene)/NO (cyclophilin A)' with NO values calculated using the LinRegPCR 7.0 (Linear Regression PCR) program (Ramakers et al. 2003, Roussel et al. 2007), followed by calculation using the $2^{-\Delta \Delta C t}$ method (Kowalewski et al. 2006).
The log-linear portion of the curve used for analysis contained four to six points, with the highest $R^{2}$ value and efficiency of amplification considered as $100 \%$.

\section{Immunohistochemistry}

Localisation of GLUT1, HIF1A and FGF2 expression was assessed via IHC on $2 \mu \mathrm{m}$ tissue sections prepared from four $\mathrm{CL}$ per dog using one section per CL and four dogs per group to assure description accuracy. The antisera used were as follows: for GLUT1, a polyclonal antibody raised in goat against human (C-20, sc-1605, dilution 1:150, Santa Cruz Biotechnology); for HIF1A, a polyclonal antibody raised in rabbit against human (NB100-134, dilution 1:400, Novus Biologicals, Littleton, CO, USA); and for FGF2, a mouse MAB (clone bFM-2, dilution 1:100, Upstate, Lake Placid, NY, USA). Standard procedures for embedding and processing $\mathrm{CL}$ tissue have been described previously (Mariani et al. 2006). Negative controls were prepared using IgG isotype control antibodies (Normal rabbit IgG for HIF1A and normal goat IgG for GLUT1; Santa Cruz Biotechnologies), while positive controls were human placenta for GLUT1 (Leon-Villapalos et al. 2005) and HIF1A (according to the manufacturer's protocol) and bovine placenta for FGF2 (Prado et al. 2004).

\section{Western blotting and quantification}

Luteal homogenates were prepared with NET-2 lysis buffer (50 mM Tris- $\mathrm{HCl}(\mathrm{pH} 7.4), 300 \mathrm{mM} \mathrm{NaCl}$ and $0.05 \% \mathrm{NP}-40$ ) containing $1 \mu \mathrm{l} / \mathrm{ml}$ protease inhibitor cocktail (Sigma-Aldrich) using a Polytron (Brinkmann Instruments, Westbury, NY, USA) and were centrifuged at $10000 \mathrm{~g}$ for $10 \mathrm{~min}$ at $4{ }^{\circ} \mathrm{C}$. The supernatants were collected, and the protein concentrations were determined using the Bradford method (Bradford 1976). Total protein was solubilised in sample buffer $(25 \mathrm{mmol} / \mathrm{l}$ Tris-Cl, pH 6.8, 1\% SDS, 5\% $\beta$-mercaptoethanol, $10 \%$ glycerol and $0.01 \%$ bromophenol blue) and incubated at $95{ }^{\circ} \mathrm{C}$ for $5 \mathrm{~min}$ prior to loading onto the gel. Twenty-five micrograms of protein were loaded onto 8 or $12 \%$ SDS-polyacrylamide gels (Mini Protean II System, Bio-Rad Laboratories, Inc.) for the quantification of HIF1A and GLUT1 protein respectively. After electrophoresis, the proteins were transferred onto a PVDF membrane (Bio-Rad Laboratories, Inc.), and the membrane was

Table 1 List of primers for real-time (TaqMan) PCR.

\begin{tabular}{|c|c|c|c|c|}
\hline Gene & Primers & Sequences & Probes & $\begin{array}{l}\text { GenBank } \\
\text { numbers }\end{array}$ \\
\hline$S L C 2 A 1$ & $\begin{array}{l}\text { Forward } \\
\text { Reverse }\end{array}$ & $\begin{array}{l}\text { 5'-CAGCCAGAGTCCСCTGTATCTA-3' } \\
5^{\prime} \text {-GTCCCСАССTTCAGGTACTG-3' }\end{array}$ & CACCCCAGACTTCACC & XM539554 \\
\hline HIF1A & $\begin{array}{l}\text { Forward } \\
\text { Reverse }\end{array}$ & $\begin{array}{l}5^{\prime} \text {-GCTGCTGGAGACACAATCATATCTT- } 3^{\prime} \\
5^{\prime} \text {-ACATCATTATACAACGGAACTTCCTCAAG- } 3^{\prime}\end{array}$ & CAATGACACAGAAACTG & XM860420 \\
\hline VEGFA & $\begin{array}{l}\text { Forward } \\
\text { Reverse }\end{array}$ & $\begin{array}{l}5^{\prime} \text {-GTGCCCACTGAGGAGTTCAAC-3' } \\
5^{\prime} \text {-CCCTATGTGCTGGCCTTGAT-3' }\end{array}$ & CACCATGCAGATTATGCGGATCAAACC & AF133248 \\
\hline FLT1 & $\begin{array}{l}\text { Forward } \\
\text { Reverse }\end{array}$ & $\begin{array}{l}\text { 5'-TGCCTGAAACAGTGAGAAAGGA-3' } \\
5^{\prime} \text {-TGCAGAACTGTTTGCCATTCC-3' }\end{array}$ & AAAGGCTGAGCATTACTAAATCTGCСТ & XM534520 \\
\hline$K D R$ & $\begin{array}{l}\text { Forward } \\
\text { Reverse }\end{array}$ & $\begin{array}{l}5^{\prime} \text {-TGAGATGGCCTCGGTCATT-3' } \\
5^{\prime} \text {-TGTTGGTCGCTAACAGAAGCA-3' }\end{array}$ & CTACGTTCAAGATTACAGGTCTCCATT & DQ269018 \\
\hline FGF2 & $\begin{array}{l}\text { Forward } \\
\text { Reverse }\end{array}$ & $\begin{array}{l}5^{\prime} \text {-CCGGTCAAGGAAATACTCCAGTTG-3' } \\
5^{\prime} \text {-GGTCCTGTTTTGGGTCCAAGTTTAT- } 3^{\prime}\end{array}$ & TATGTGGCACTGAAACGA & AF060562.1 \\
\hline Cyclophilin A & Forward & ID Cf03986523_gH & & XM_843327.1 \\
\hline
\end{tabular}


incubated in blocking buffer containing $5 \%$ non-fat dry milk for $1 \mathrm{~h}$ at room temperature. The membrane was then probed with primary antibodies (anti-GLUT1, 1:500, C-20, sc-1605, Santa Cruz Biotechnology; anti-HIF1A, dilution 1:500, NB100-134, Novus Biologicals and anti-ACTB, Clone AC-15, dilution 1:500, A1978, Sigma-Aldrich Co., as the reference protein) overnight at $4{ }^{\circ} \mathrm{C}$, followed by probing with Ig-HRP antibodies (anti-rabbit IgG for HIF1A and ACTB and anti-goat IgG for GLUT1; Amersham Biosciences) diluted in a 2.5\% non-fat dried milk solution for $1 \mathrm{~h}$ at room temperature. The immunocomplexes were then visualised using ECL, as recommended by the manufacturer (Amersham Biosciences). The validation of both antibodies for canine tissue was performed using human placenta. The proteins were examined by measuring the specific bands using a ChemiDoc MP Imaging System (Bio-Rad Laboratories) and normalised to $\beta$-actin (ACTB; $42 \mathrm{kDa}$ ) using ImageJ Software (Bio-Rad Laboratories).

\section{Determination of plasma $P_{4}$ and $E_{2}$ concentrations}

After collection, blood samples $(5 \mathrm{ml})$ were centrifuged for $10 \mathrm{~min}$ at $300 \mathrm{~g}, 4{ }^{\circ} \mathrm{C}$. The serum samples were stored at $-20{ }^{\circ} \mathrm{C}$ until $\mathrm{P}_{4}$ and $\mathrm{E}_{2}$ determination by validated chemiluminescence immunoassay. The low limit detection of the $\mathrm{P}_{4}$ and $E_{2}$ assays was $0.03 \mathrm{ng} / \mathrm{ml}$ and $0.5 \mathrm{pg} / \mathrm{ml}$ respectively. The inter-assay coefficient of variation (CV) for $\mathrm{P}_{4}$ and $\mathrm{E}_{2}$ was 6.93 and $7.03 \%$ respectively. The intra-assay CV was $<10 \%$ for both hormones.

\section{Statistical analysis}

All the experiments were performed at least three times with a minimum of three repeats, including western blotting analyses. Dependent variables (i.e. steroid production and gene and protein expression of SLC2A1/GLUT1, HIF1A, VEGFA, FLT1, KDR and FGF2) were analysed by Kruskal-Wallis test followed by Dunn's multiple comparison test. The correlations between hormone concentrations and gene or protein expression levels were determined using the Pearson's Correlation test. Response variables were tested according to their homogeneity and normality of variances. Data are presented as mean \pm S.E.M. Statistical analyses were performed using the GraphPad Prism 4 program (GraphPad Software, Inc.). Differences with $P$ value $<0.05$ were considered significant.

\section{Results}

\section{Homology cloning of canine KDR}

The available predicted sequence of canine KDR was used for the homology cloning procedure. Consequently, the canine-specific sequence was amplified, cloned and submitted to GenBank under access number GI: 82548234. This sequence comprises 4068 nucleotides of a predicted ORF of canine KDR, which encodes a 1355 amino acid protein with a deduced molecular weight of $152 \mathrm{kDa}$. BLAST analysis showed 97, 92, 90 and $85 \%$ homology with human (GI: 231570519), pig
(GI: 7160277), bovine (Gl: 61884824) and mouse (GI: 27777647) KDR sequences respectively. According to the published canine genome sequence, the KDR sequence is located on chromosome 13.

\section{Expression of SCL2A1-, HIF1A-, FGF2-, VEGFA-, FLT1 - and KDR $m R N A$}

The expression of six target genes directly involved in the response of the $\mathrm{CL}$ against fluctuations in substrate availability and oxygen tension in luteal cells was investigated. Dioestrus had an effect of time on the expression of SCL2A1 $(P=0.002), H I F 1 A(P<0.001)$, FGF2 and the VEGF system $(P=0.002$; Fig. 1). SCL2A1 (Fig. 1A) and HIF1A (Fig. 1B) expression levels increased on day 20 p.o., decreased at mid dioestrus (days 30 and 40 p.o.), increased again on days 50 and 60 p.o. $(P<0.05)$ and were significantly down-regulated at the beginning of anoestrus (day 70 p.o.; $P<0.05$ ). The FGF2 expression increased on day 30 p.o. and decreased thereafter until day 60 p.o. $(P<0.05$; Fig. 1C). VEGFA (Fig. 1D) and FLT1 (Fig. 1E) expression levels were significantly elevated on days 20 and 60 p.o., while the $K D R$ expression levels were elevated on days 20 and 40 p.o. $(P<0.05$; Fig. 1F).

\section{Spatial expression of GLUT1, HIF1A, and FGF2 assessed via IHC}

GLUT1 and HIF proteins were localised in the dog CL over dioestrus. Immunopositive staining could be observed restricted to the cytoplasm of luteal,
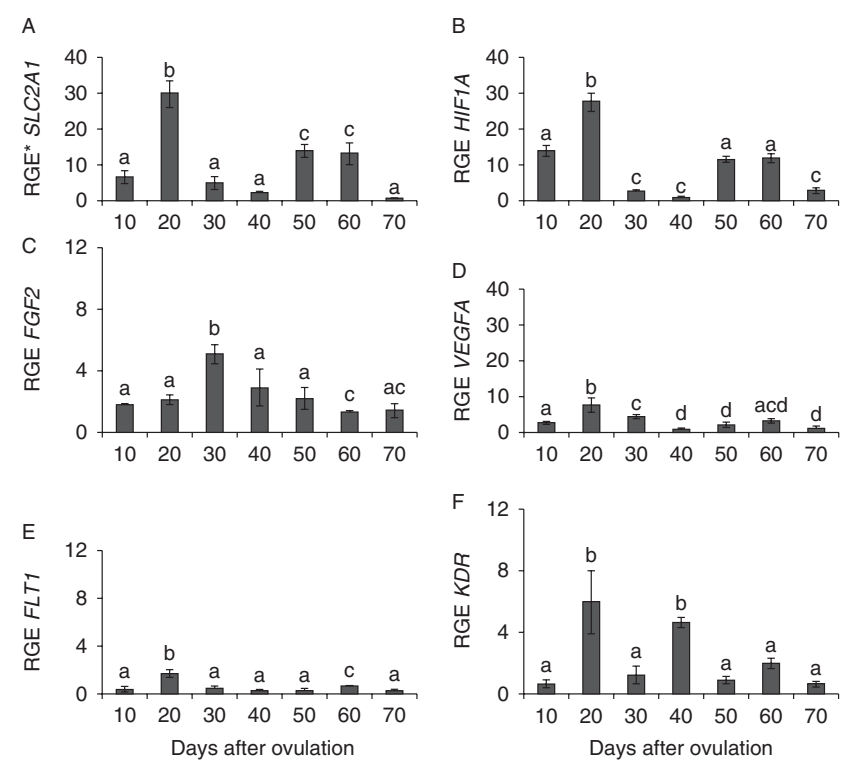

Figure $1 S L C 2 A 1$ (A), HIF1A (B), FGF2 (C), VEGFA (D), FLT1 (E) and $K D R$ (F) expression levels in the canine $\mathrm{CL}$ ( $n=28$; four per group) determined via real-time (TaqMan) PCR. RGE, relative gene expression (mean \pm s.E.M.) normalised to cyclophilin A. Bars with different letters represent significant differences $(P<0.05) ; 10-70$ : days after ovulation. 
endothelial and stromal cells in all phases studied (days 10-70 p.o.; Figs 2 and 3). Besides the cytoplasm staining, the nuclear staining of HIF1A from day 30 until 60 could also be observed. However, no positive staining could be observed in the negative control. Positive control (human placenta, PC; Figs 2 and 3) showed a marked positive staining.

Positive immunostaining for FGF2 was observed in the cytoplasm of luteal, endothelial and stromal cells (Fig. 4); positive staining was observed primarily in stromal cells on day 10 p.o. and in luteal cells on day 20 p.o. By day 30 p.o., luteal cells displayed marked positive immunostaining, while stromal cells were primarily negative. By days 50 and 60, FGF2 signals appeared weaker; however, at day 70 , the cytoplasmic staining levels were evident again. Bovine CL served as positive control (Prado et al. 2004), and the negative control revealed no staining for FGF2 (Insert on Fig. 4).

\section{Quantification of GLUT1 and HIF1A protein expression via western blotting and the correlation with the respective gene expression levels}

We observed that time had an effect on the expression of both GLUT1 $(P=0.04)$ and HIF1A $(P<0.0001$; Fig. 5). GLUT1 expression increased on day $20(P<0.05)$, decreased on day 30 and showed a tendency to increase on day 40 p.o., but no further variations until day 70 p.o. (Fig. 5B; $P>0.05$ ) were observed. This expression pattern highly correlates with the $S C L 2 A 1$ expression during the first half of dioestrus $(r=0.83 ; P=0.009)$. The HIF1A expression (Fig. 5D) showed an increase on day 30 p.o. followed by a further increase on day 60 p.o.

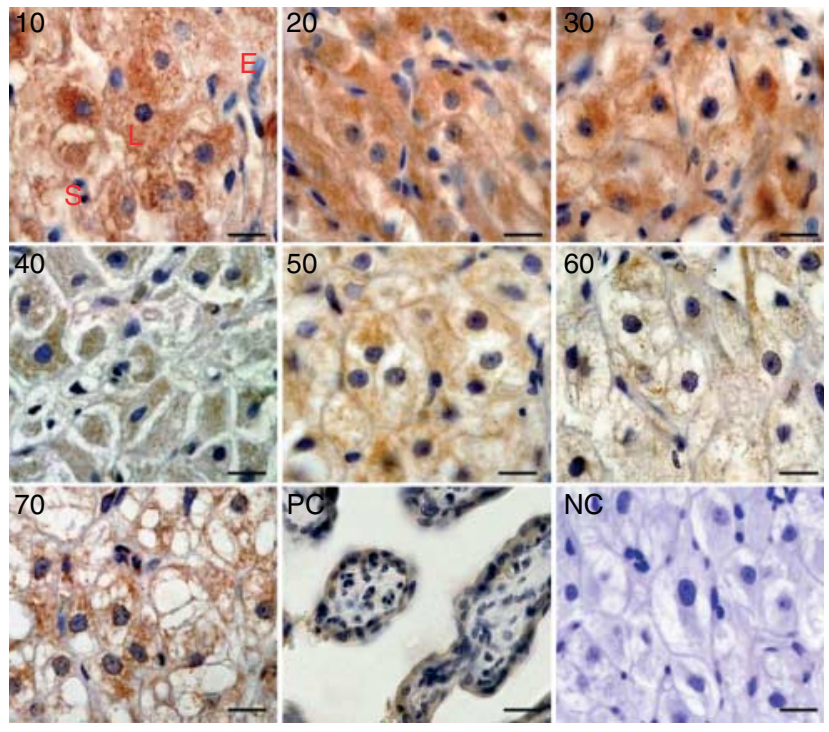

Figure 2 GLUT1 staining in the canine CL assessed by immunohistochemistry. Positive signals (orange-brown colour) were observed in the cytoplasm of luteal (L), endothelial $(\mathrm{E})$ and stromal $(\mathrm{S})$ cells at days 10, 20, 30, 40, 50, 60 and 70 after ovulation. PC, positive control (human placenta); NC, negative control. Bars $=50 \mu \mathrm{m}$.

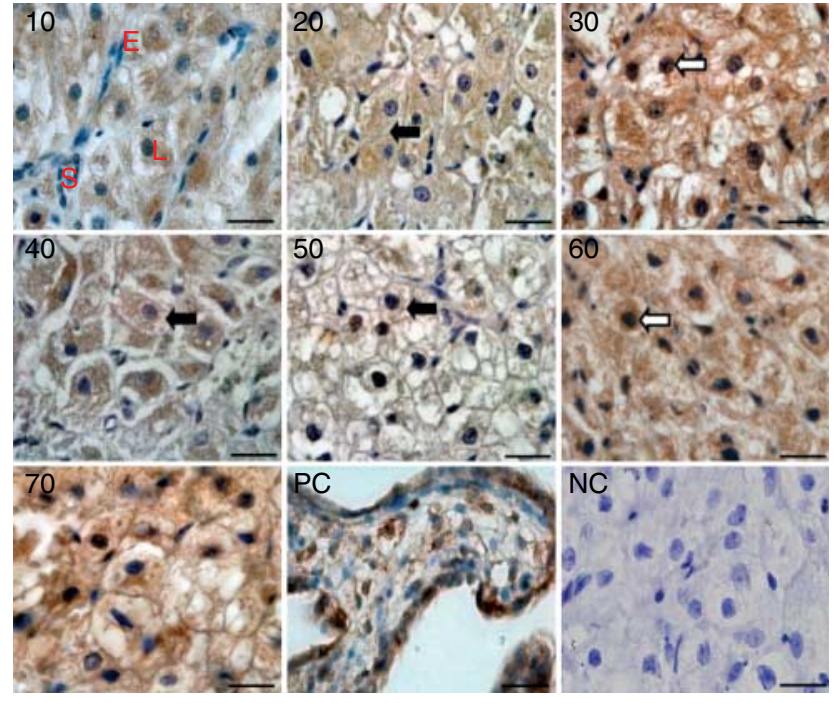

Figure 3 HIF1A staining in the canine CL assessed by immunohistochemistry. Positive signals in the cytoplasm (black arrows) and the nucleus (white arrows) of luteal cells (L) were observed on days 10, 20, 30, 40, 50, 60 and 70 after ovulation. PC, positive control (human placenta); $\mathrm{NC}$, negative control. Bars $=50 \mu \mathrm{m}$.

and a final decrease on day 70 p.o. $(P<0.05)$. In contrast to GLUT1, HIF1A protein was negatively correlated with its mRNA expression in the same period $(r=-0.86$; $P=0.005)$.

\section{Plasma steroid hormone profiles}

$\mathrm{P}_{4}$ plasma concentrations were highest on day 20 and displayed a distinct and continuous decrease thereafter (Fig. 6A; $P<0.05$ ). The concentrations of $E_{2}$ increased from days 10 to 40 p.o. followed by a gradual decrease thereafter (Fig. 6B; $P<0.05$ ).

\section{The correlation between hormone concentrations and gene expression}

A significant positive correlation during the first half of dioestrus was observed between $\mathrm{P}_{4}$ levels and the expression levels of all genes studied (Table 2), except for FGF2, whose expression pattern positively correlated with $E_{2}$ levels throughout the entire observation period $(r=0.61 ; P=0.01)$. Positive and significant correlation was observed among the expressions of HIF1A and SCL2A1, HIF1A and VEGF, VEGFA and FLT1, VEGF and $S C L 2 A 1$, and FLT1 and SCL2A1 (Table 2).

\section{Correlations of hormone concentrations and protein expression assessed by western blotting}

During the first half of dioestrus, the GLUT1 expression was positively correlated with $\mathrm{P}_{4}$ plasma concentration $(r=0.86 ; P=0.005)$ and negatively correlated with the expression of HIF1A $(r=-0.77 ; P=0.02)$, while both 


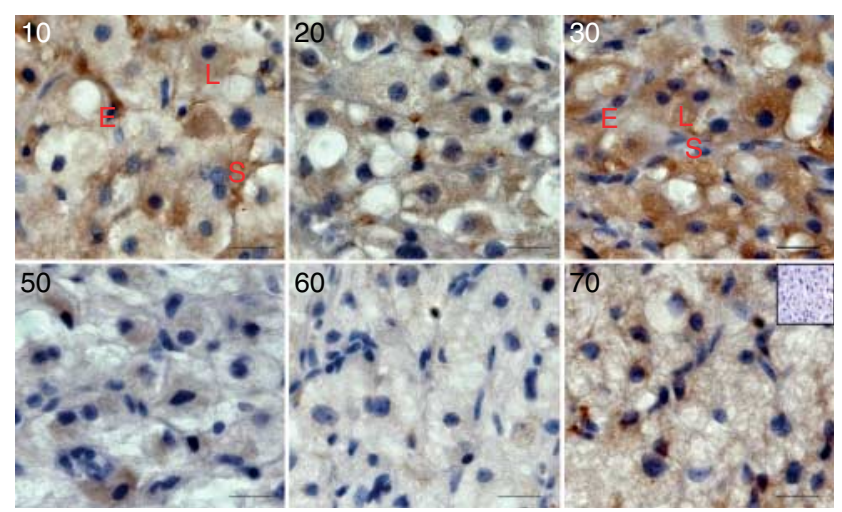

Figure 4 FGF2 staining in the canine CL assessed by immunohistochemistry. Positive signals were observed as indicated by the brown colour in the cytoplasm of luteal (L), endothelial (E) and stromal (S) cells at 10, 20,30, 50, 60 and 70 days after ovulation. Bars $=20 \mu \mathrm{m}$.

proteins showed no significant correlation with the $\mathrm{E}_{2}$ plasma concentration $(r=-0.15 ; P=0.73$ and $r=-0.38 ; P=0.39$ respectively).

\section{Discussion}

According to our hypothesis, the expression of HIF1A at the mRNA level, which is a factor sensitive to decreased tissue/cell $\mathrm{O}_{2}$ concentrations, was positively correlated with the expression of SLC2A1, VEGFA, the VEGFA receptor FLT1 and FGF2 during the entire period of dioestrus. Additionally, the mRNA expression of these factors accompanied fluctuations of $\mathrm{P}_{4}$ concentrations during the first half of dioestrus, thereby indicating the importance of these factors during $\mathrm{CL}$ formation.

These observations of the up-regulation of the 'glucose transport system' matching that of factors that play a role in angiogenesis raise the question of the underlying triggering mechanisms. Although hypoxia occurs during the initial phase of CL formation (Nishimura et al. 2010), the function of $\mathrm{P}_{4}$ and perhaps that of $\mathrm{E}_{2}$ should also be considered.

In addition to its function as an endocrine factor, the observations in cattle suggest that $\mathrm{P}_{4}$ may also act as a local luteotrophic factor, capable of exerting a positive feedback loop on its receptor (Schams \& Berisha 2004). Observations in dogs, in which the application of a $\mathrm{P}_{4}$ receptor inhibitor results in preterm luteolysis, further support the hypothesis concerning a luteotrophic function of $\mathrm{P}_{4}$ in the canine $\mathrm{CL}$ (Kowalewski et al. 2009, 2010).

It has also been reported that $\mathrm{P}_{4}$ directly regulates $S C L 2 A 1$ expression in endometrial cells (Frolova et al. 2009, Kim \& Moley 2009) via its own receptor (Frolova et al. 2009), thereby activating the intracellular signalling pathway and enhancing GLUT1 expression levels and translocation to the plasma membrane (Kim \& Moley 2009). Both studies suggest an opposite function for $E_{2}$, i.e. the down-regulation of $S C L 2 A 1 / G L U T 1$, when tested alone or in combination with $\mathrm{P}_{4}$. Moreover, blocking the oestrogen receptor 1 (ESR1) with ICI 182780 restored the expression of SCL2A1/GLUT1 (Kim \& Moley 2009). Incorporating these data into the context of the canine luteal function, it is possible that $\mathrm{P}_{4}$ acts in the same way by enhancing SCL2A1/GLUT1 expression via signalling through its receptor (Hoffmann et al. 2004, Papa \& Hoffmann 2011), which results in an increased availability of glucose, thereby reinforcing the concept that increased luteal glucose uptake (Palfreyman et al. 1992) corresponds to a higher steroidogenic output. In contrast to what has been observed for the $\operatorname{dog} C L$ in this study, Nishimoto et al. (2006) described, in cattle, no cycle-related SCL2A1 expression in the early or mid luteal phase but a decrease in the late luteal phase. These differences may also rely on the local interplay between $\mathrm{P}_{4}$ and $\mathrm{E}_{2}$, which reaches its highest levels in cows when the $\mathrm{CL}$ regresses, but not during the

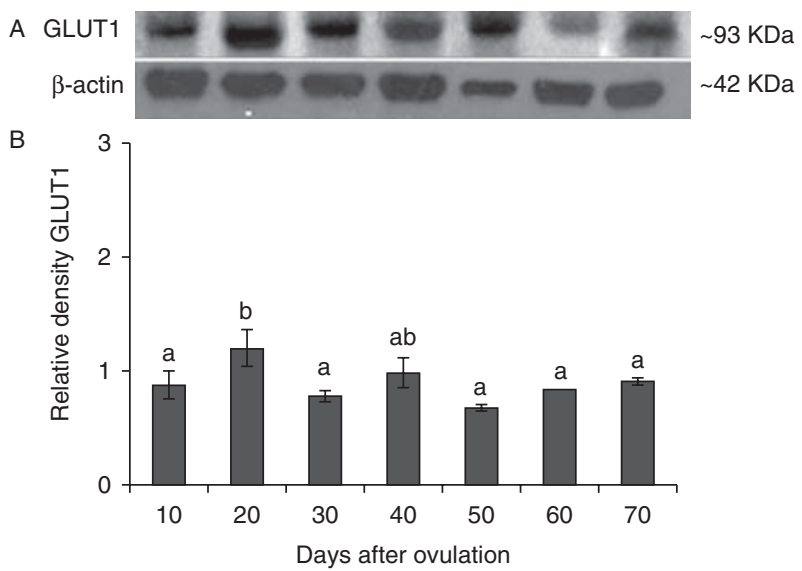

C
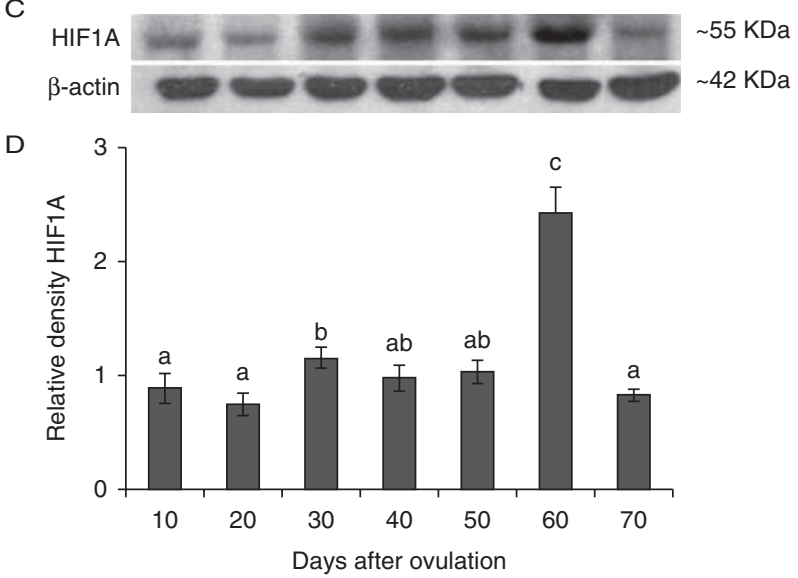

Figure 5 Protein expression of GLUT1 (A and B) and HIF1A (C and D) in the canine $C L$ during dioestrus ( $n=28$; four animals per group). Electrophoresis images are representative of three independent experiments. The total protein isolated from luteal homogenates was examined with specific antibodies and normalised to ACTB expression. The data are expressed as the mean \pm s.E.M. Bars with different letters indicate a significant difference $(P<0.05)$. 

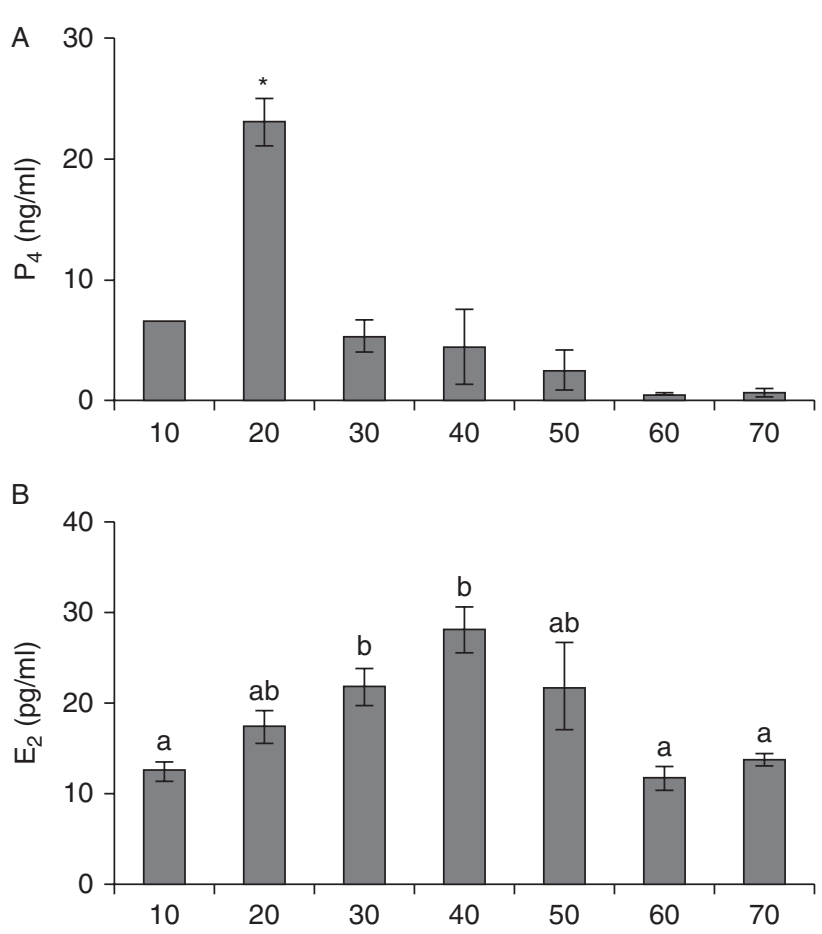

Figure 6 Plasma $\mathrm{P}_{4}(\mathrm{ng} / \mathrm{ml} ; \mathrm{A})$ and $\mathrm{E}_{2}(\mathrm{pg} / \mathrm{ml} ; \mathrm{B})$ profiles during dioestrus determined via chemiluminescence ( $n=28$; four animals per group). The data are presented as the mean \pm S.E.M. Asterisks or different letters indicate a significant difference $(P<0.05)$.

early or mid luteal phase, in which $\mathrm{P}_{4}$ governs alone (revised by Sartori \& Barros (2011)).

$\mathrm{E}_{2}$ levels were positively correlated with the FGF2 expression pattern, which seems to contribute to maintaining angiogenesis when VEGFA starts decreasing. Both angiogenic factors play complementary roles in $\mathrm{CL}$ vascularisation, as already described for cattle (Schams \& Berisha 2004), and VEGFA responds to hypoxia (Neeman et al. 1997). Additionally, Kihira et al. (2011) described FGF2 as an enhancer of SCL2A1 expression in cultured 3T3-L1 adipocytes, but further studies are necessary to characterise species and tissue specificities concerning the function of FGF2 in this respect.

The role of hypoxia during $\mathrm{CL}$ formation was recently addressed in cattle (Nishimura et al. 2010) and seemed to relate directly to the formation of the vascular bed by inducing the expression of VEGF. VEGFA protein and its receptors are expressed in the canine $\mathrm{CL}$ throughout dioestrus with a decrease after day 40 p.o. and unaltered receptor (FLT1 and KDR) protein expression (Mariani et al. 2006), which was confirmed in this study for expression at the mRNA level. In addition to its paramount role in angiogenesis, VEGFA may also be considered a luteotrophic factor, as it enhances $\mathrm{P}_{4}$ production in bovine placental cells in vitro (Sousa et al. 2012) and induces STAR expression in bovine luteal cells (Yamashita et al. 2008). In this study, VEGFA expression was highly correlated, at the mRNA level $(r=0.85$; $P=0.01$ ), with plasma $P_{4}$ levels, thereby suggesting the function of a luteotrophic factor in dogs. The HIF1A expression accompanied that of VEGFA and SCL2A1 as stated above. According to our findings, the canine $\mathrm{CL}$ detected the first $\mathrm{O}_{2}$ imbalance at day 30 p.o., as revealed by western blotting analysis of HIF1A, which did not decrease until day 60 p.o., when it experienced a further and abrupt increase. This corroborates with findings by Hoffmann et al. (2004), who observed a decreased density of luteal cells from day 30 of dioestrus onwards. Similarly, Nishimura et al. (2008) reported a decrease in blood perfusion to bovine $\mathrm{CL}$ followed first by hypoxia and then by functional and finally structural luteolysis. The presence of the HIF1A protein in the nuclei on day 50 p.o., concomitant to increased levels of HIF1A mRNA and subsequent to increased HIF1A protein on day 60 p.o., matches a moment in the $\mathrm{CL}$ lifespan, in which levels of luteal $\mathrm{P}_{4}$ are decreasing and first signs of structural regression can be observed (Sonnack 2009). The correlation observed between the expression levels of HIF1A, VEGFA and SCL2A1 at the mRNA level suggests a functional inter-relationship that results in the formation of GLUT1 protein. However, further evidence must be provided, and the sequence of events is unclear.

While our data concerning expression at the mRNA level seem to yield a rather clear picture, the whole situation becomes somewhat less clear when taking the protein data into account. Therefore, the concentrations of GLUT1 protein seem to be parallel to some extent to the relative gene expression of SCL2A1. Concerning the HIF1A protein, there was a negative correlation with its

Table 2 Correlation coefficients between steroid production and gene expression in canine CL during dioestrus.

\begin{tabular}{|c|c|c|}
\hline Variables & Pearson's $r$ & $P$ value \\
\hline $\mathrm{P}_{4}$ vs HIF1A & 0.78 & $0.03^{\mathrm{a}}$ \\
\hline $\mathrm{P}_{4}$ vs $S L C 2 A 1$ & 0.79 & $0.03^{\mathrm{a}}$ \\
\hline $\mathrm{P}_{4}$ vs VEGFA & 0.85 & $0.01^{\mathrm{a}}$ \\
\hline $\mathrm{P}_{4}$ vs $F L T 1$ & 0.90 & $0.005^{\mathrm{a}}$ \\
\hline $\mathrm{P}_{4}$ vs $K D R$ & 0.76 & $0.04^{\mathrm{a}}$ \\
\hline $\mathrm{P}_{4}$ vs $F G F 2$ & 0.05 & 0.84 \\
\hline $\mathrm{E}_{2}$ vs HIF1A & -0.38 & 0.39 \\
\hline $\mathrm{E}_{2}$ vs $S L C 2 \mathrm{~A} 1$ & -0.15 & 0.73 \\
\hline $\mathrm{E}_{2}$ vs VEGFA & -0.15 & 0.73 \\
\hline $\mathrm{E}_{2}$ vs $F L T 1$ & -0.21 & 0.64 \\
\hline $\mathrm{E}_{2}$ vs $K D R$ & 0.38 & 0.39 \\
\hline $\mathrm{E}_{2}$ vs $F G F 2$ & 0.61 & $0.01^{b}$ \\
\hline HIF1A vs $S L C 2 A 1$ & 0.93 & $0.002^{\mathrm{b}}$ \\
\hline HIF1A vs VEGFA & 0.98 & $0.03^{b}$ \\
\hline HIF1A vs FLT1 & 0.84 & $0.01^{b}$ \\
\hline HIF1A vs FGF2 & -0.37 & 0.18 \\
\hline SLC $2 A 1$ vs VEGFA & 0.84 & $0.001^{\mathrm{b}}$ \\
\hline$S L C 2 A 1$ vs FLT1 & 0.83 & $0.007^{b}$ \\
\hline$S L C 2 A 1$ vs $F G F 2$ & -0.21 & 0.46 \\
\hline VEGFA vs FLT1 & 0.93 & $0.002^{b}$ \\
\hline VEGFA vs $K D R$ & 0.53 & 0.21 \\
\hline$V E G F A$ vs FGF2 & 0.17 & 0.55 \\
\hline
\end{tabular}

${ }^{\mathrm{a}}$ Correlated in first half of dioestrus (days 10, 20 and 30 p.o.).

${ }^{\mathrm{b}}$ Correlated throughout dioestrus. 
expression at the mRNA level; this observation suggests other post-translational regulatory factors, which may become activated in the ageing $\mathrm{CL}$, and stresses the likely importance of $\mathrm{P}_{4}$ concerning the up-regulation of $S C L 2 A 1$, as was emphasised by observations on day 20, indicating that a function-associated $\mathrm{O}_{2}$ imbalance may not occur prior to approximately day 60, which represents the time point when Sonnack (2009) observed the first signs of structural luteolysis.

By presenting the expression of GLUT1 and its associated regulatory proteins, our data suggest new regulatory factors possibly involved in canine $\mathrm{CL}$. This concerns mostly the first half of dioestrus, on the one hand, when the canine $C L$ is being formed and passes through its highest steroidogenic and metabolic capacity. On the other hand, for the second half of canine dioestrus (Okkens et al. 1990), prolactin appears to be the most important luteotrophic factor.

In conclusion, our data reveal a local time-dependent system comprising hypoxia sensing, induction of angiogenesis and glucose uptake, orchestrated by or influencing $\mathrm{P}_{4}$ secretion, especially in the first half of dioestrus in the canine $\mathrm{CL}$.

\section{Declaration of interest}

The authors declare that there is no conflict of interest that could be perceived as prejudicing the impartiality of the research reported.

\section{Funding}

This research was financially supported by FAPESP (grant numbers 2008/54835-8, 2010/07373-9 and 2011/17768-3) and CAPES (025/2011).

\section{Acknowledgements}

The authors thank Dr Adauri Brezolin for the English revision of the manuscript.

\section{References}

Andersen CL, Jensen JL \& Orntoft TF 2004 Normalization of real-time quantitative reverse transcription-PCR data: a model-based variance estimation approach to identify genes suited for normalization, applied to bladder and colon cancer data sets. Cancer Research 64 5245-5250. (doi:10.1158/0008-5472.CAN-04-0496)

Bradford MM 1976 A rapid and sensitive method for the quantitation of microgram quantities of protein utilizing the principle of protein-dye binding. Analytical Biochemistry 72 248-254. (doi:10.1016/00032697(76)90527-3)

Campos DB, Papa PC, Marques JE Jr, Garbelotti F, Fatima LA, Artoni LP, Birgel EH Jr, Meirelles FV, Buratini J Jr, Leiser R et al. 2010 Somatic cell nuclear transfer is associated with altered expression of angiogenic factor systems in bovine placentomes at term. Genetics and Molecular Research 9 309-323. (doi:10.4238/vol9-1gmr729)

Concannon PW, McCann JP \& Temple M 1989 Biology and endocrinology of ovulation, pregnancy and parturition in the dog. Journal of Reproduction and Fertility. Supplement 39 3-25.
Downing JA, Joss J \& Scaramuzzi RJ 1995 Ovulation rate and the concentrations of gonadotrophins and metabolic hormones in ewes infused with glucose during the late luteal phase of the oestrous cycle. Journal of Endocrinology 146 403-410. (doi:10.1677/joe.0.1460403)

van den Driesche S, Myers M, Gay E, Thong KJ \& Duncan WC 2008 HCG up-regulates hypoxia inducible factor- $1 \alpha$ in luteinized granulosa cells: implications for the hormonal regulation of vascular endothelial growth factor $\mathrm{A}$ in the human corpus luteum. Molecular Human Reproduction 14 455-464. (doi:10.1093/molehr/gan040)

Duncan WC, van den Driesche S \& Fraser HM 2008 Inhibition of vascular endothelial growth factor in the primate ovary up-regulates hypoxiainducible factor- $1 \alpha$ in the follicle and corpus luteum. Endocrinology 149 3313-3320. (doi:10.1210/en.2007-1649)

Engel E, Klein R, Baumgartner W \& Hoffmann B 2005 Investigations on the expression of cytokines in the canine corpus luteum in relation to dioestrus. Animal Reproduction Science 87 163-176. (doi:10.1016/ j.anireprosci.2004.10.002)

Ferrara N, Chen H, Davis-Smyth T, Gerber HP, Nguyen TN, Peers D, Chisholm V, Hillan KJ \& Schwall RH 1998 Vascular endothelial growth factor is essential for corpus luteum angiogenesis. Nature Medicine 4 336-340. (doi:10.1038/nm0398-336)

Frolova A, Flessner L, Chi M, Kim ST, Foyouzi-Yousefi N \& Moley KH 2009 Facilitative glucose transporter type 1 is differentially regulated by progesterone and estrogen in murine and human endometrial stromal cells. Endocrinology 150 1512-1520. (doi:10.1210/en.2008-1081)

Hoffmann B, Höveler R, Hasan SH \& Failing K 1992 Ovarian and pituitary function in dogs after hysterectomy. Journal of Reproduction and Fertility 96 837-845. (doi:10.1530/jrf.0.0960837)

Hoffmann B, Busges F, Engel E, Kowalewski MP \& Papa P 2004 Regulation of corpus luteum-function in the bitch. Reproduction in Domestic Animals 39 232-240. (doi:10.1111/j.1439-0531.2004.00508.x)

Kihira Y, Yamano N, Izawa-Ishizawa Y, Ishizawa K, Ikeda Y, Tsuchiya K, Tamaki T \& Tomita S 2011 Basic fibroblast growth factor regulates glucose metabolism through glucose transporter 1 induced by hypoxiainducible factor- $1 \alpha$ in adipocytes. International Journal of Biochemistry \& Cell Biology 43 1602-1611. (doi:10.1016/j.biocel.2011.07.009)

Kim ST \& Moley KH 2009 Regulation of facilitative glucose transporters and AKT/MAPK/PRKAA signaling via estradiol and progesterone in the mouse uterine epithelium. Biology of Reproduction 81 188-198. (doi:10.1095/ biolreprod.108.072629)

Kowalewski MP \& Hoffmann B 2008 Molecular cloning and expression of StAR protein in the canine corpus luteum during dioestrus. Experimental and Clinical Endocrinology \& Diabetes 116 158-161. (doi:10.1055/ s-2007-992121)

Kowalewski MP, Mason JI, Howie AF, Morley SD, Schuler G \& Hoffmann B 2006 Characterization of the canine $3 \beta$-hydroxysteroid dehydrogenase and its expression in the corpus luteum during diestrus. Journal of Steroid Biochemistry and Molecular Biology 101 254-262. (doi:10.1016/ j.jsbmb.2006.06.029)

Kowalewski MP, Mutembei HM \& Hoffmann B 2008a Canine prostaglandin $E_{2}$ synthase (PGES) and its receptors (EP2 and EP4): expression in the corpus luteum during dioestrus. Animal Reproduction Science 109 319-329. (doi:10.1016/j.anireprosci.2007.11.023)

Kowalewski MP, Mutembei HM \& Hoffmann B 2008 $b$ Canine prostaglandin $\mathrm{F} 2 \alpha$ receptor (FP) and prostaglandin F2 $\alpha$ synthase (PGFS): molecular cloning and expression in the corpus luteum. Animal Reproduction Science 107 161-175. (doi:10.1016/j.anireprosci.2007.06.026)

Kowalewski MP, Beceriklisoy HB, Aslan S, Agaoglu AR \& Hoffmann B 2009 Time related changes in luteal prostaglandin synthesis and steroidogenic capacity during pregnancy, normal and antiprogestin induced luteolysis in the bitch. Animal Reproduction Science 116 129-138. (doi:10.1016/ j.anireprosci.2008.12.011)

Kowalewski MP, Beceriklisoy HB, Pfarrer C, Aslan S, Kindahl H, Kücükaslan I \& Hoffmann B 2010 Canine placenta: a source of prepartal prostaglandins during normal and antiprogestin-induced parturition. Reproduction 139 655-664. (doi:10.1530/REP-09-0140)

Leon-Villapalos J, Wolfe K \& Kangesu L 2005 GLUT-1: an extra diagnostic tool to differentiate between haemangiomas and vascular malformations. British Journal of Plastic Surgery 58 348-352. (doi:10.1016/j.bjps.2004. 05.029)

Mariani TC, do Prado C, Silva LG, Paarmann FA, Lima MC, Carvalho I, Campos DB, Artoni LP, Hernandez-Blazquez FJ \& Papa P 2006 
Immunohistochemical localization of VEGF and its receptors in the corpus luteum of the bitch during diestrus and anestrus. Theriogenology 66 1715-1720. (doi:10.1016/j.theriogenology.2006.02.030)

Mattmiller SA, Corl CM, Gandy JC, Loor JJ \& Sordillo LM 2011 Glucose transporter and hypoxia-associated gene expression in the mammary gland of transition dairy cattle. Journal of Dairy Science 94 2912-2922. (doi:10.3168/jds.2010-3936)

Neeman M, Abramovitch R, Schiffenbauer YS \& Tempel C 1997 Regulation of angiogenesis by hypoxic stress: from solid tumours to the ovarian follicle. International Journal of Experimental Pathology 78 57-70. (doi:10.1046/j.1365-2613.1997.d01-247.x)

Nishimoto H, Matsutani R, Yamamoto S, Takahashi T, Hayashi KG, Miyamoto A, Hamano S \& Tetsuka M 2006 Gene expression of glucose transporter (GLUT) 1, 3 and 4 in bovine follicle and corpus luteum. Journal of Endocrinology 188 111-119. (doi:10.1677/joe.1.06210)

Nishimura R \& Okuda K 2010 Hypoxia is important for establishing vascularization during corpus luteum formation in cattle. Journal of Reproduction and Development 56 110-116. (doi:10.1262/jrd.09-162E)

Nishimura R, Komiyama J, Tasaki Y, Acosta TJ \& Okuda K 2008 Hypoxia promotes luteal cell death in bovine corpus luteum. Biology of Reproduction 78 529-536. (doi:10.1095/biolreprod.107.063370)

Nishimura A, Sugita M, Kato K, Fukuda A, Sudo A \& Uchida A 2010 Hypoxia increases muscle hypertrophy induced by resistance training. International Journal of Sports Physiology and Performance 5 497-508.

Okkens A \& Bevers M 1990 Evidence for prolactin as the main luteotropic factor in the cyclic dog. Veterinary Quarterly 12 193-201.

Papa PC \& Hoffmann B 2011 The corpus luteum of the dog: source and target of steroid hormones? Reproduction in Domestic Animals 46 750-756. (doi:10.1111/j.1439-0531.2010.01749.x)

Palfreyman RW, Clark AE, Denton RM \& Holman D 1992 Kinetic resolution of the separate GLUT1 and GLUT4 glucose transport activities in 3T3-L1 cells. Biochemical Journal 284 275-282.

Prado C, Garbelotti F, Artoni LP, Campos DB, Pfarrer C \& Papa PC 2004 Immunolocalization of FGF2 in the corpus luteum of buffalos in different stages of the estrous cycle. Arquivos de Ciências da Saúde da UNIPAR 8 39-41.

Ramakers C, Ruijter JM, Deprez RH \& Moorman AF 2003 Assumptionfree analysis of quantitative real-time polymerase chain reaction (PCR) data. Neuroscience Letters 339 62-66. (doi:10.1016/S0304-3940(02) 01423-4)

Roussel Y, Harris A, Lee MH \& Wilks M 2007 Novel methods of quantitative real-time PCR data analysis in a murine Helicobacter pylori vaccine model. Vaccine 25 2919-2929. (doi:10.1016/j.vaccine.2006.07.013)

Sartori R \& Barros CM 2011 Reproductive cycles in Bos indicus cattle. Animal Reproduction Science 124 244-250. (doi:10.1016/j.anireprosci. 2011.02.006)
Schams D \& Berisha B 2004 Regulation of corpus luteum function in cattlean overview. Reproduction in Domestic Animals 39 241-251. (doi:10.1111/j.1439-0531.2004.00509.x)

Sone H, Deo BK \& Kumagai AK 2000 Enhancement of glucose transport by vascular endothelial growth factor in retinal endothelial cells. Investigative Ophthalmology \& Visual Science 41 1876-1884.

Songsasen N, Fickes A, Pukazhenthi BS \& Wildt DE 2009 Follicular morphology, oocyte diameter and localisation of fibroblast growth factors in the domestic dog ovary. Reproduction in Domestic Animals 44 (Suppl 2) 65-70. (doi:10.1111/j.1439-0531.2009.01424.x)

Sonnack M 2009 Untersuchungen zur Bildung, regression and Funktionalitat des Corpus Luteum der nicht graviden Hundin, morphologische and biochemische Aspeckte. PhD thesis. pp1-117 VVB Laufersweiler Verlag, Giessen: Germany.

Sousa LM, Campos DB, Fonseca VU, Viau P, Kfoury JR, Oliveira CA, Binelli M, Buratini J \& Papa PC 2012 Vascular endothelial growth factor A (VEGFA) modulates bovine placenta steroidogenesis in vitro. Placenta 33 788-794. (doi:10.1016/j.placenta.2012.07.009)

Takagi H, King GL \& Aiello LP 1998 Hypoxia upregulates glucose transport activity through an adenosine-mediated increase of GLUT1 expression in retinal capillary endothelial cells. Diabetes 47 1480-1488. (doi:10.2337/diabetes.47.9.1480)

Wang GL \& Semenza GL 1993 General involvement of hypoxia-inducible factor 1 in transcriptional response to hypoxia. PNAS 90 4304-4308. (doi:10.1073/pnas.90.9.4304)

Yamashita H, Kamada D, Shirasuna K, Matsui M, Shimizu T, Kida K, Berisha B, Schams D \& Miyamoto A 2008 Effect of local neutralization of basic fibroblast growth factor or vascular endothelial growth factor by a specific antibody on the development of the corpus luteum in the cow. Molecular Reproduction and Development 75 1449-1456. (doi:10.1002/mrd.20878)

Zhang Z, Yin D \& Wang Z 2011 Contribution of hypoxia-inducible factor$1 \alpha$ to transcriptional regulation of vascular endothelial growth factor in bovine developing luteal cells. Animal Science Journal 82 244-250. (doi:10.1111/j.1740-0929.2010.00832.x)

Zhao FQ \& Keating AF 2007 Expression and regulation of glucose transporters in the bovine mammary gland. Journal of Dairy Science 90 (Suppl 1) E76-E86. (doi:10.3168/jds.2006-470)

Received 21 August 2013

First decision 19 September 2013

Revised manuscript received 9 October 2013

Accepted 18 October 2013 